\title{
Capital account liberalization and its effects on economic growth and financial instability: the exante orthodox models were wrong
}

\author{
Liberalização da conta financeira e seus efeitos \\ sobre crescimento econômico e instabilidade financeira: \\ os modelos ortodoxos exante estavam errados
}

\author{
DIEGO GARCIA ANGELICO* \\ GIULIANO CONTENTO DE OLIVEIRA**
}

\begin{abstract}
RESUMO: As crises financeiras nas economias emergentes durante os anos 1990 e 2000 impulsionaram a academia e as instituições multilaterais a investigar se os benefícios prometidos pela abertura financeira estavam sendo observados. No decorrer de estudos empíricos sobre o tema, diversos pressupostos teóricos formulados exante sobre globalização financeira foram desmistificados, e diversos riscos e disfunções até então desconhecidos começaram a ficar evidentes. Este artigo analisa os principais estudos empíricos mainstream sobre os efeitos da globalização financeira publicados nas últimas duas décadas e mostra que os principais pressupostos convencionais que foram formulados para sustentar teoricamente os processos de liberalização da conta financeira que ocorreram ao longo dos anos 1980 e 1990 estavam equivocados.
\end{abstract}

PALAVRAS-CHAVE: Globalização financeira; liberalização da conta financeira; mainstream economics; instabilidade financeira; economias emergentes.

ABSTRACT: The financial crises in emerging economies during the 1990s and 2000s propelled academia and multilateral institutions to investigate whether the promised benefits of capital account liberalization were being delivered or not. In the course of empirical studies on the subject, many ex ante theoretical assumptions on financial globalization were demystified, and previously unknown risks and dysfunctions began to be evidenced. This article analyzes the main empirical studies on the effects of financial globalization published in the last two

\footnotetext{
* Doctoral student at Instituto de Economia da Universidade de Campinas - IE/Unicamp and researcher at Centro de Estudos de Relações Econômicas Internacionais - Ceri - IE/Unicamp, Campinas/SP, Brasil. E-mail: diego_angelico@hotmail.com. Orcid: https://orcid.org/0000-0002-4606-3408.

* Professor at Instituto de Economia da Universidade de Campinas - IE/Unicamp and researcher at Centro de Estudos de Relações Econômicas Internacionais - Ceri - IE/Unicamp, Campinas-SP, Brasil. E-mail: giueco@unicamp.br. Orcid: https://orcid.org/0000-0001-6791-2643. Submitted: 3/February/ 2020; Approved: 25/March/2020.
} 
decades and shows that the main conventional assumptions that were built to theoretically base the capital account liberalization processes that occurred in the 1980s and 1990s were wrong.

KEYWORDS: Financial globalization; capital account liberalization; mainstream economics; financial instability; emerging economies.

JEL Classification: F3; F4; F6.

\section{INTRODUCTION}

The advent of the current phase of financial globalization took form in the capital account liberalization processes pursued by advanced countries during the 1980s and by the so-called emerging economies during the subsequent decade. Besides all the geopolitical conjunctures that motivated the transition to a new International Monetary and Financial System (IMFS), several theoretical presumptions were constructed in order to ground the supposed benefits of a free capital mobility.

According to such presumptions (ex-ante orthodox models), the removal of the remaining capital controls would especially guarantee greater rates of economic growth, automatic adjustments in key macroeconomic variables, and longterm stability. Therefore, it could be observed that these axioms, which were influenced by the New Macroeconomic Consensus, ${ }^{1}$ were guided by orthodox principles.

After the demise of the Bretton Woods System, the world has been observing increasing financial instability, a greater divergence between the economic growth of countries and global imbalances, besides other dysfunctions that have been counterpointing the above-mentioned presumptions.

In this perspective, this article conducted a review of the mainstream literature that empirically investigated the impact that capital account liberalization has been having on several countries, especially emerging ones. These studies that began to appear even in the 1990s were preoccupied with developing quantitative methods to test the validity of each theoretical construction that grounded the advent of liberalized global finance. It was possible to discover important changes in the mainstream literature on capital account liberalization, since this process did not generate the promised benefits.

Apart from the introduction and conclusion, this article is divided as follows: second section presents a brief description of the principle orthodox presumptions that theoretically grounded the process of external financial openness; The third section 3 , in turn, is subdivided into surveys on the correlations between financial globalization and the principle orthodox presumptions presented, as well as surveys on papers that investigated recent impacts fostered by liberalized global finance on emerging countries.

\footnotetext{
${ }^{1}$ In summary, an approach based on conclusions of New Keynesian macroeconomics. See Arestis (2009).
} 
A capital account liberalization process is characterized by the removal of controls on international capital flows, which in turn allows free mobility of private capital portfolios among different countries and markets. According to Prasad et al. (2003), the main expected benefits that capital account liberalization can be briefly subdivided into direct and indirect effects on economic growth. For the orthodox or neoclassical tradition, in the first class of effects, an increase in financial integration should lead to: i) an increase in the economy's total saving (by means of external savings absorption); ii) better risk sharing, which in turn reduces capital costs; iii) technology transference, due to Foreign Direct Investments (FDIs); and iv) greater development of the financial system.

Additionally, there are the indirect channels, by which greater financial integration should lead to increased economic growth and operate by means of an increased effectiveness of economic policy as well as corporative governance. These effects would occur due to the constant evaluation performed by financial markets and due to the increase in the total factor productivity (TFP).

Another financial liberalization benefit defended by orthodox literature is the intertemporal consumption smoothing due to the greater development of the financial system following a capital account liberalization process. This because the development of financial instruments that allowed residents to acquire foreign assets as well as an increase in external liability issues would theoretically lead to a convergence of the consumption volatility among different countries (Prasad et al., 2003). ${ }^{2}$

During the decade characterized by the insertion of the so-called emerging countries into financial globalization, the then IMF executive-director Fisher (1997) also defended capital account liberalization as an economic growth stimulator, since this processes would allow a more efficient allocation of financial resources, i.e., in sectors that presented higher productivity. This assumption would be even more relevant for developing economies, which show capital scarcity and an abundance of labor supply, which in turn would allow an increase in the investment rate even in a context of a low domestic saving rate.

According to Dooley (1996), an important assumption that boosted the capital account liberalization processes was that there would be expected returns convergence among different countries, equated by the uncovered interest rate parity theory (UIP). ${ }^{3}$ This potential benefit would be greater in developing and emerging economies, since these countries had been historically characterized for presenting relatively higher interest rates. In this perspective, external financial openness would lead to expected returns convergence since these processes were accompanied by

\footnotetext{
2 The orthodox approach assumes that a capital account liberalization can induce productive specialization or a higher degree of productive diversification.

${ }^{3}$ For more details about the literature on UIP, see Alper et al. (2009).
} 
structural reforms, including those destined to make feasible the superiority of monetary policy to act on aggregate demand, relative to fiscal policy.

In parallel to the presumptions described above, orthodox theory also defended that a floating exchange rate system would guarantee auto corrective movements in exchange rate in order to reflect the country's current account structure. In this way, the capital account liberalization should theoretically correct any disequilibrium in a country's balance of payments. The development of the domestic financial system due to the exposure to foreign competition, among other factors, promote an increase in risk sharing capacity due to a higher degree of financial integration, contributing to exchange rate adjustment (Fisher, 1997). ${ }^{4}$

According to this conventional thought, emerging economies would potentially have greater benefits from risk sharing processes, since the majority of their foreign assets are the public bonds of developed countries. Since advanced economies, in turn, generally invest in the private assets of emerging countries, they are relatively more exposed to greater price volatility during financial crises. Therefore, theoretically, there would be greater risk sharing for emerging economies during financial crises.

However, most of such theoretical assumptions were not fully observed during the last decades of financial globalization. Indeed, some new evidence showed the opposite of these expected outcomes. The following section presents the main empirical studies on this subject.

\section{EMPIRICAL COUNTERPOINTS TO ORTHODOXY}

Despite all the conventional constructs that theoretically grounded the process of external financial openness, several studies within mainstream economics and the International Monetary Fund (IMF) have been contradicting these presumptions over the last two decades. It is understood that this movement was a reaction to the crises of emerging economies that took place in the mid-1990s and beginning of the first decade of the twenty-first century (which we shall refer to as the 00s).

Besides the development of these empirical studies (counterfactuals), extensive literature concerned with developing studies and sophisticated techniques designated to evidence several risks that emerging countries are exposed to under the current international financial system started to stand out. These new studies started to emphasize the sudden stops (an abrupt decrease or interruption of the private capital inflows into the economies, typically in developing ones), reversals (an intense reduction in the domestic absorption due to a sudden stop, since current

\footnotetext{
${ }^{4}$ The implicit premise in this defense is that a de jure capital account liberalization, i.e., the removal of remaining controls in the capital account, leads to a de facto financial integration (the sum of foreign gross assets and liabilities) in a similar proportion.
} 
account deficit is generally financed by capital inflows), currency mismatches, and loss of monetary policy autonomy, among other risks.

\section{Economic growth and consumption volatility}

As described above, one of the presumptions that grounded the financial deregulation processes was that this process would raise the investment rate and the economic growth. In addition, would reduce the intertemporal consumption volatility. These benefits would be potentially greater for developing countries, especially.

One of the more embracing papers on this subject was the one developed by Prasad et al. (2003). The authors conducted an empirical study on several emerging economies in order to evaluate the impact that financial globalization had been having on these countries.

A first their analysis showed that financial liberalization is neither a necessary nor a sufficient condition to stimulate higher rates of economic growth, since there were relatively closed countries that presented expressive rates of economic growth and open economies that presented low or even negative rates. ${ }^{5} \mathrm{~A}$ second analysis made by Prasad et al. (2003) consisted of a correlation estimation between the financial integration level and the growth rate of real per capita GDP for a group of emerging economies. ${ }^{6}$ This method did not establish a robust relation between financial integration and economic growth.

Prasad et al. (2003) also provided an important contribution to the other abovementioned assumption, i.e., that financial globalization reduces consumption volatility and/or variance. The authors investigated the evolution of the variance of aggregate components, such as private consumption, GDP, and consumption/income for a group of developed and emerging economies. The latter was divided into 'more financially integrated' (MFI) and 'less financially integrated' (LFI) countries. ${ }^{7}$

These estimations showed a very important result for the emerging economies within the sample. The variances of both private consumption and consumption/ income dropped more dramatically for LFI emerging countries over the whole period. In addition, Prasad et al. (2003) showed that the above-mentioned variances arose during the 1990s for the MFI countries.

Given these results, Prasad et al. (2003) pointed out the procyclical behavior of international financial markets and rating agencies lead to procyclical movements in domestic consumption. This means that the presumption that greater fi-

\footnotetext{
${ }^{5}$ Prasad et al. (2003) analyzed 12 emerging economies for the period 1980-2000.

${ }^{6}$ The authors selected 12 emerging economies during the period 1982-1997. The methodology of financial integration is the one developed by Lane and Milesi-Ferreti (2007).

${ }^{7}$ The method used by Prasad et al. (2003) consisted of calculating the standard deviation of the abovementioned macroeconomic aggregates. The analysis period covered 1960 to 1999 and was also subdivided into decades.
} 
nancial integration would optimize the intertemporal consumption volatility of emerging economies lacked evidence.

Several other studies pointed out a similar lack of evidence on the subject. The survey published by Kose et al. (2006) contributed to establishing this stylized fact: several papers that aimed to establish a direct correlation between international financial integration and economic growth could not find such a correlation. ${ }^{8}$ In relation to the presumption of intertemporal consumption smoothing due to greater degree of financial integration, Kose et al. (2006) pointed out that this synchrony has occurred more significantly among advanced countries, while emerging economies have been showing higher rates of consumption volatility. Therefore, there was not the expected risk diversification.

Facing several papers that showed the failures of such orthodox presumptions, Rodrik and Subramanian (2009) aimed to identify the reasons why foreign savings were not stimulating higher rates of economic growth in most cases. This paper stood out since it constituted an empirical and theoretical counterpoint to the above-mentioned orthodox presumption. The authors estimated regressions (and correlation estimations) for a group of emerging economies and evidenced the absence of any correlation among the variables selected. ${ }^{9}$ They also counterpointed the argument that the positive effects of capital account liberalization would take a while to be observed, ${ }^{10}$ since the estimations calculated were temporally very wide-ranging.

Given the results, Rodrik and Subramanian (2009) presented an important theoretical innovation on capital account liberalization and economic growth that had not been debated by the mainstream economics until then. According to the authors, emerging economies can be characterized as 'saving constrained' (SC) or 'investment constrained' (IC), in such a way that the effects of capital inflows radically change depending on the group into which each country fits. The first class of emerging economies is characterized by the showing of a low domestic saving rate and high real interest rates. The main restriction of these countries is the lack of accumulated saving stock for the concretization of investments. In that way, for the authors the implications of the orthodox approach could (but not necessarily) be valid for them.

However, several emerging economies belong to the 'investment constrained' (IC) group. Their main restriction is the lack of investment demand due to an expectation of insufficient profitably from the execution of new projects. For this

\footnotetext{
${ }^{8}$ The cross-country regression elaborated by Kose et al. (2006) also showed the absence of such a correlation. The period of analysis covered 1985-2004.

${ }^{9}$ Rodrik and Subramanian (2009) performed these regressions for the periods of 1970-2004 and 1985-2004. The authors used measures of de facto financial integration based in Lane and Milesi-Ferreti (2007). The regressions pointed to a lack of a robust correlation between external financial openness and higher rates of economic growth.
}

${ }^{10}$ See Henry (2007) and Prasad et al. (2003). 
group, the orthodox approach would not be valid, since a great deal of financial inflows would not function as productive capital for new investments. On the contrary, these capital inflows, by the exchange rate appreciation, foster a negative externality in other sectors, in such a way that the investment rate of tradable sectors is negatively affected, bringing negative implications for long-term economic growth. ${ }^{11}$

It is important to note that Bresser-Pereira and Nakano (2003) had shown years before the absence of relationship between foreign saving and economic growth from the so-called substitution effect. That is, the exchange rate appreciation generated by the inflow of foreign capital increases the real wage and consequently the domestic consumption. In effect, this movement reduces the domestic savings, neutralizing the increase of foreign savings and its potentially expansive effects on economic growth. Therefore, domestic savings are replaced by foreign savings. Some years later, Bresser-Pereira and Gala (2007) demonstrated this empirically.

From that, Rodrik and Subramanian (2009) investigated to what degree emerging countries fit SC or IC groups. ${ }^{12}$ The regressions elaborated by the authors showed that the emerging countries analyzed were mainly characterized as 'investment constrained' economies, for which the orthodox assumption that full external financial openness promote higher economic growth has little validity.

Lastly, the authors aimed to identify the common determinants of emerging economies that presented higher rates of economic growth over the period between 1980 and 2004. The regressions established a positive relation among the rates of exchange rate devaluation, a proxy for the development of domestic financial systems, and the economic growth of these economies. ${ }^{13}$ These results evidenced that the emerging countries that presented higher rates of economic growth over the last decades of financial globalization accomplished it through internally funding their investments, and not through reverting to foreign savings. ${ }^{14}$ Rodrik (2006) argued that the monetary policy of capital inflows sterilization causes a higher participation of public bonds in the private sector portfolio, i.e., a great deal of capital inflows are not channeled into productive investments assets. ${ }^{15}$

\footnotetext{
${ }^{11}$ According to Rodrik and Subramanian (2009), capital that flows to IC economies can increase investment in non-tradable sectors, especially because domestic currency gets valorized in this context. However, this effect is overcome, in terms of long-term economic growth, for the reduction of investment rate in tradable sectors.

${ }^{12}$ For the countries to be characterized in the first group, commensurate with the orthodox approach, capital inflows must have a direct relation to the investment/GDP rate of emerging economies. Alternatively, international interest rates must have an inverse relation to the investment/GDP rate of emerging economies.

${ }^{13}$ Such as described, the development of the domestic financial system, in improving the channeling of domestic savings to tradable sectors, can reduce the pressure on exchange rate appreciation.

${ }^{14}$ Prasad et al. (2007) also found this conclusion through different methods.

${ }^{15}$ Rodrik (2006) shows for a group of emerging economies that the international reserves (IR) have
} 
Therefore, one can see that these important empirical studies established an absence of robust effects of the capital account liberalization on economic growth and intertemporal consumption volatility, often pointing out an opposite relationship to that supposed by conventional theory. These counterintuitive results also stimulated research to find the causes of such negative results, which were also not put forward by international finance theorists in the 1980s and 1990s.

\section{Original sin and debt intolerance}

Several peculiar characteristics of emerging economies that were not contemplated by the conventional apparatus during the liberalizing reforms based on exante orthodox models were only recognized years after the occurrence of financial crises in these countries. One of these characteristics refers to restrictions on the issue of external liabilities imposed on emerging and developing countries, since the access to international financial markets depends on the dynamic of important wealth managers, such as the institutional investors. In other words, the access to "foreign savings" as a determinant of the economic growth of emerging economies does not appear as preconized by theory. Among the main phenomena identified by mainstream economists in the beginning of the 00s, original sin and debt intolerance stood out.

Among the pioneers to identify the causes of such restrictions were Eichengreen et al. (2003). It was evidenced that some of the divergence of economic policies between developed and emerging countries has the fact that cross borders financial transactions are denominated in a small number of strong currencies as a main cause. Put another way, emerging countries cannot contract foreign debt in their own currencies. This restriction was then called "original sin".

Another important contribution presented by Eichengreen et al. (2003) was that original sin can be domestically manifested in emerging economies. When instated, it produces side effects in relation to the composition of their domestic public debt securities (DPDS). The indicator presented by the authors ${ }^{16}$ showed that the lack of a currency convertibility in international markets reflects on the composition of the DPDS in such a way that a substantial portion of public bonds is denominated in a strong currency and/or are short-term bonds, and/or are interest rates post fixed bonds.

strongly increased since the 1990s, a consequence of the increase of capital inflows to these economies. However, the M2/IR indicator was relatively constant during this period, indicating that a significant part of these capital inflows was accompanied by sterilization policy, since the M2 monetary aggregate includes public bonds. Furthermore, the Gross fixed capital formation/GDP rate in these countries dropped sharply from the mid-1990s to the mid-00s, a period in which several of these countries were strengthening their external financial openness processes.

16 This indicator captures the representativeness of bonds that have an unfavorable indexation (denomination in a foreign currency, short-term bonds, and interest rate post-fixed bonds) on the total of a given country's DPDS. 
In this way, when an economy presents an unfavorable indexation of its DPDS, a loss of autonomy in implementing domestic policies takes place, since public debt gets exposed to exchange rate, interest rate, and inflation variability. Furthermore, the lack of a distinct separation between public debt management and monetary policy inhibits the latter's effectiveness and imposes high financial costs to the public budget.

In order to demonstrate other difficulties that emerging economies incur due to original sin, Eichengreen et al. (2003) showed that the real GDP volatility (quoted in American dollars) of these countries - an indicator in analyzing the payment capacity of foreign debt - was approximately three times greater in relation to the same indicator shown by developed countries. That, in turn, has been negatively affecting the credit rating of emerging countries.

It is noteworthy that the economic growth volatility of emerging economies is high due to their real exchange rate variability, this last condition being due to original sin. This phenomenon also took place in the medium and long term, which in turn contradicted the orthodox assumption that in the long run there would not be a differential in exchange rate volatility between developed and emerging countries. ${ }^{17}$

Besides that, another side effect is the higher volatility of the domestic interest rate, what in turn feeds back on the incapacity of these economies to issue bonds in international markets that are denominated in their own currencies. It can also induce the proliferation of domestic debt contracts with a foreign exchange clause - a process that discourages the development of the domestic financial system by inhibiting the launch of long-term pre-fixed bonds. One can observe that this last possible side effect is clearly the opposite to the assumption that full external financial openness would promote the development of the domestic financial system (Eichengreen et al., 2003).

However, the recognition that emerging and developing countries face more obstacles when managing foreign debt had other justifications of causality. The thesis that emerging countries are subjected to 'debt intolerance' when trying to access global financial markets deserves a careful analysis. Reinhart et al. (2003) showed that emerging economies that had just a low level of foreign debt acceptable by foreign investors had common historical factors that include periods of high inflation and foreign debt defaults. Therefore, the delay in financial and tax systems due to these factors creates a vicious cycle in which these countries would have to maintain low levels of foreign debt and higher interest rates in order to attract capital inflows.

The regression elaborated by the authors also showed that the current credit

\footnotetext{
17 The study elaborated by Eichengreen et al. (2003) covered the period 1980-1999. It is noteworthy that the volatility of the real exchange rate of emerging economies showed a similar magnitude between 1 year and 5 years moving average, both for the decades of 1980s and 1990s, being from twice to three times greater than the volatility of the real exchange rate of advanced economies.
} 
ratings of emerging economies had a negative correlation with the history of defaults and inflation, and foreign debt cycles, while the hypothesis that the ratings of developed countries had a positive correlation with their public debt level was confirmed. Therefore, the authors empirically demonstrated that emerging economies were susceptible to ratings downgrades when they increased their level of foreign indebtedness. It is noteworthy that a rating downgrade to the 'debt intolerance' level is accompanied by an increase in the risk premium demanded by foreign investors.

The authors also performed a regression in which the dollarization level of a given economy - measured by the share of dollar deposits in the financial system and by the percentage of public bonds indexed to the exchange rate - had a direct relation to the debt intolerance incidence. It is notable that in those cases the higher the dollarization level, the lower the autonomy in implementing domestic policies was. ${ }^{18}$

Reinhart et al. (2003) also attributed the growth of domestic public debt that took place within emerging countries to the financial liberalization processes that occurred mainly in the 1990s. Within this context, there was also a significant difference between emerging economies characterized by incurring debt intolerance and those that showed a better external insertion. On the one hand, for the first group of countries there was, in a general way, an increase in both the fiscal deficit and public debt interest rate. On the other hand, an opposite movement took place for the second group of countries, i.e., the liberalizing reforms affected the public accounts and DPDS of emerging countries characterized for presenting debt intolerance negatively and more intensively.

Within the debate that took place during the 00s about the main causes of unfavorable external insertion of emerging economies, the paper published by Eichengreen et al. (2007) reaffirmed the influence that international financial architecture exercises on this process. More precisely, the authors provided important evidence that pointed to the fact that original sin was the cause of most divergences between emerging and developed countries, including the occurrence of debt intolerance. It is notable that they admitted that net capital flows do not dislocate from rich to poor countries, such as defended by orthodox theory, since international finance displays pro-cyclical behavior.

In response to the debt intolerance thesis defended by Reinhart et al. (2003), Eichengreen et al. (2007) called attention to the fact that all emerging economies that showed difficulties in managing levels of foreign indebtedness had in common the fact that none of their currencies was internationally convertible. This factor, in turn, generates a strong divergence between developed and emerging countries in

\footnotetext{
18 The regressions elaborated by Reinhart et al. (2003) used the dollarization index as a dependent variable, and the following independent variables: both inflation rate history and foreign debt restructuring episodes, and the level of foreign debt to GDP, for the period 1996-2001. All independent variables presented a direct relation to the dollarization index.
} 
relation to foreign restriction issues. Another problem presented by economies that incur original sin is a currency mismatch, since their external liabilities are mostly denominated in a foreign currency, while their assets are mainly denominated in their domestic currency.

In this way, in order to counterpoint the debt intolerance thesis, the regression estimated by Eichengreen et al. (2007) established that there was, on the one hand, a negative correlation between the ratings of these countries and their original sin indicators..$^{19}$ On the other hand, the volatility of the real exchange rate tended to be stronger in countries that presented a relatively open capital account and a high share of commodities in total exports.

Still in response to the debt intolerance thesis, Eichengreen et al. (2007) also estimated a regression in order to analyze the relationship between a given country's foreign liabilities level and its rating, in such a way that the original sin indicator could be utilized as a control variable. The results found were extremely important, since there was only a negative correlation between external liabilities and ratings when the original sin indicator did not control the regression. However, this negative correlation lost statistical significance when the above-mentioned control was performed. ${ }^{20}$

Furthermore, Eichengreen et al. (2007) established that there was a positive correlation among the presence of original sin and the measures of exchange rate, capital flows, and economic growth volatilities, even when the regressions were controlled by a debt intolerance indicator. ${ }^{21}$ Therefore, these additional regressions also established greater influence of original sin in explaining the different behaviors and volatilities of these economic variables between developed and emerging economies.

Thus, contrary to the debt intolerance advocates, the original sin literature recognizes the existence of a hierarchy of currencies in the international monetary system. This mean that emerging and developing countries cannot issue significant amounts of external debts in their own currency and, therefore, external financial openness does not play the same financing role as it plays for developed countries whose currencies are internationally convertible.

\section{Sudden stops and reversals}

The unstable dynamics of the current International Monetary and Financial System have also had divergences pointing out between developed and emerging

\footnotetext{
${ }^{19}$ These regressions were controlled by the following variables: per capita GDP, total debt/GDP, foreign debt/GDP, volatility of terms of trade, and volatility of the real exchange rate.

20 The authors also controlled the regressions by the countries' level of development, i.e., between developed and developing economies.

${ }^{21}$ The inclusion of a debt intolerance indicator as a control variable did not show statistical significance and the results remained the same.
} 
countries in relation to frequency of access in the global financial markets. The financial crises of mid-1990s and beginning of the 00s took the mainstream economics to recognize that capital flows are unstable, and it causes negative effects on emerging economies, especially. These events were respectively denominated sudden stops and reversals.

One of the first studies to call attention to this unpredictability of external financing was published by Rodrik and Velásco (1999). The authors analyzed currency and financial crises that hit emerging economies in the 1990s and concluded that these crises originated in the capital accounts of these economies, meaning that any economic policy that was intended to reduce the level of domestic absorption would be ineffective. According to the theoretical model elaborated by the authors, the interest rate structure of external financing is endogenous to the agents, ${ }^{22}$ in such a way that the rolling over of foreign liabilities depends on the creditors' confidence level in relation to the volume of short-term foreign liabilities (STFL) contracted by the investors.

However, according to the authors an optimum level of volume and structure of foreign liabilities, determined by private agents, generally results in the contraction of a high volume of STFL, in such a way that the risks of long-term foreign liabilities defaulting (in the case of the absence of STFL rolling over) has the side effect of raising its interest rate, feeding back into this vicious cycle. ${ }^{23}$

Put another way, according to Rodrik and Velásco (1999), due to factors such as the absence of agent risk internalization in their financing operations and information asymmetry, the market can lead to a macroeconomic scenario characterized by a sum of short-term foreign liabilities that exceed the volume of international reserves (IR), generating balance of payments crises and insolvency.

In order to corroborate their model, Rodrik and Velásco (1999) performed a regression to identify the connection between the 'STFL/IR' indicator and the financial crises, measured as sudden stops, for a group of emerging economies over the 1990s. ${ }^{24}$ The results showed that the higher the 'STFL/IR' indicator, the higher the probability of financial crises occurring. Besides that, when a sudden stop took place, the effects on currency devaluation and recessive impacts also had a direct relation to the 'STFL/IR' level that was in force before the occurrence of the financial crisis.

The increasing differences between emerging and advanced economies in global financial markets continued to incentivize studies aimed at quantifying the im-

\footnotetext{
${ }^{22}$ Given the fact that short-term foreign liabilities (STFL) present an inferior perceived risk in relation to long-term liabilities, because they have a relatively inferior liquidation deadline, agents attribute inferior interest rates to STFL.

${ }^{23}$ Rodrik and Velásco (1999) used this theoretical construction to explain the crises of emerging economies in the 1990s.

24 The regression elaborated by Rodrik and Velásco (1999) included 23 emerging economies for the period of 1988-1998. The debt inflows were divided into long, medium and short term.
} 
pacts that external financial deregulation had been having on each kind of economy. In this sense, the capital account liberalization indicator constructed by Edwards (2007) and its relations with the financial vulnerabilities of economies was an important contribution to this literature..$^{25}$

Based on the above-mentioned capital account liberalization indicator, this author aimed to identify a relation among sudden stops, reversals, and degree of capital mobility existing in several countries. ${ }^{26} \mathrm{~A}$ first estimation developed by the author showed that emerging and developing countries showed, on average, a higher frequency of sudden stops and reversals in relation to developed economies, which, in turn, showed a low incidence of these two events.

The regressions elaborated by the author especially deserve highlighting. In relation to developed economies, the regressions established that the higher the degree of capital mobility, the lower the frequency (or probability) of these economies incurring sudden stops and reversals. Nevertheless, the regressions elaborated for the conjunct of emerging economies - specifically the Asian economies ${ }^{27}$ - established contrary behavior, i.e., the probability of these economies incurring sudden stops and reversals increased with the higher the degree of their capital mobility, while this probability (or frequency) decreased with the lower the degree of their capital account liberalization.

These results suggest that financial globalization has been functional for advanced countries in relation to external financing, while it has been riskier for emerging and developing economies, even when these two groups of countries present similar degrees of de jure capital account liberalization. In other words, financial globalization has not been homogeneous in the financing of all countries, nor even delivering equal risk sharing among them, thus revealing its structural asymmetry.

It has been increasingly evident that emerging economies had been facing unfavorable conditions when trying to get stable foreign funding, and in regard to that several papers aimed to investigate the main exogenous factors, as well as the main domestic determinants of sudden stops and reversals. The intention was to find solutions that could partially soften the adverse effects of such events on emerging economies. One good example of such a study was that developed by Calvo et al. (2004), according to which episodes characterized by sudden stops of foreign financing are typical of emerging countries, so much so that several of these countries have already suffered the contagious effects of sudden stops, despite hav-

\footnotetext{
${ }^{25}$ The indicator of capital mobility mainly considers the degree of (de)regulation on the capital account, but also includes a measure of commercial integration. For more details see Edwards (2007).

${ }^{26}$ The regressions developed by Edwards (2007) covered the period of 1970-2000. The countries present in the sample were grouped according to their income level.

27 The regressions performed for the conjunct of Latin American countries did not show statistical significance. These results hold for both regressions that used 1-year and 5-years moving averages.
} 
ing different levels of public debt. ${ }^{28}$ It is noteworthy that according to the regressions performed by Calvo et al. (2004), the probability of the occurrence of sudden stops increased with the higher the level of foreign liabilities contracted by the domestic financial system, and the higher the sensibility of the real exchange rate in relation to the current account deficits of those economies. ${ }^{29}$

Another relevant point derived from the regressions elaborated by Calvo et al. (2004) referred to the strong difference observed between emerging and developed economies in relation to the consequence of incidences of sudden stops. The regressions estimated by the authors showed that the increase of the real interest rate and the reversals magnitude were, on average, three and five times greater for emerging economies vis-à-vis developed countries respectively. In addition, in some cases when a sudden stop endured, the use of international reserves became innocuous.

Therefore, the architecture of the current International Monetary and Financial System contributes, per se, to sudden stops of the external financing of emerging economies, a condition that results in the subordinate insertion of these economies into financial globalization.

\section{Procyclical capital flows, risk sharing, and monetary policy independence}

One of the theoretical presumptions that grounded the capital account liberalization processes was that capital flows would inflow countercyclically to the domestic economic activity of countries in order to correct, mainly, the balance of payments imbalances. In turn, this process would promote intertemporal consumption and income smoothing, and this benefit would be potentially greater for developing and emerging countries..$^{30}$ Similarly, a higher degree of financial integration among countries would make an increase in risk sharing between domestic and foreign agents possible.

However, such has been discussed, the evidence pointed out unexpected effects beyond the strong divergences between advanced and emerging economies, which had until then not been seen in orthodox approach. Particularly, the study published by Kaminsky et al. (2004) stood out for demystifying some theses about international financial markets, especially the assumption that external financing would always be countercyclical to domestic economic activity. ${ }^{31}$

\footnotetext{
${ }^{28}$ Calvo et al. (2004) pointed out that some emerging economies that were hit by sudden stops had levels of public debt inferior to the ones observed for advanced economies.

${ }^{29}$ It is notable that the measure of real exchange rate sensibility to external deficit considered the ratio between absorption of tradable products and domestic production. The higher this ratio was, the higher was the real exchange rate sensibility.

${ }^{30}$ The regressions performed by Calvo et al. (2004) covered the period of 1990-2001 and contemplated 15 emerging and 17 developed economies.

${ }^{31}$ Were covered 104 economies and subdivided them into economies belonging to ODCE (21) and 'non-ODCE' countries. The period of analysis was from 1960 to 2003.
} 
When focusing on the macroeconomic response of countries in relation to business cycles, the authors showed that for both groups of countries analyzed, net capital inflows were procyclical to business cycles. In addition, while ODCE countries succeeded in implementing countercyclical fiscal policies over the analyzed period, the non-ODCE economies implemented procyclical fiscal policies in relation to business cycles.

Kaminsky et al. (2004) also showed relevant differences between the two groups of countries. Correlation calculus showed that ODCE countries succeeded in implementing countercyclical fiscal and monetary policies in relation to net capital inflows, while non-ODCE countries, in special medium-income emerging economies, responded to net capital inflows by implementing procyclical fiscal and monetary policies.

In this way, Kaminsky et al. (2004) pointed out that a monetary policy that is pro-cyclical to net capital inflows is a major characteristic of emerging economies, since these countries do not have the uninterrupted access to external financing that ODCE countries do. Indeed, the analysis of the amplitude and coefficient of variation of net capital inflows established that emerging economies showed much higher values than ODCE economies did. Therefore, emerging economies implemented expansionist monetary policies while in phases of external bonanza, and while in contexts of low global liquidity these economies were forced to practice a monetary contraction in order to attract capital inflows and to reduce domestic absorption, so they could honor foreign liabilities services. In other words, during this second context, emerging economies generally incur in financial constraint.

Moreover Kaminsky et al. (2004) showed that the ratings attributed by risk agencies to emerging economies were procyclical to their business cycles. This process, in turn, has been contributing to the increase of the amplitude of net capital inflows over the phases of boom and bust in these countries.

Underlying the presumption that capital inflows would be countercyclical to business cycles, a process of financial liberalization should be accompanied by the implementation of a floating exchange rate regime in order to guarantee automatic adjustments in balance of payments. Given the procyclical behavior of net capital flows, several studies started to point out the absence of such automatic adjustments and, consequently, mechanisms present in the exchange rate of emerging economies that were divergent from the ones preconized in orthodox theory. The paper published by Calvo and Reinhart (2002), in which the expression "fear of floating" was coined, deeply investigated such macroeconomic relations.

The estimations performed by Calvo and Reinhart (2002) showed that emerging economies that claimed to adopt a floating exchange rate regime presented a high variability in their international reserves and interest rates as a counterpart to smooth excessive exchange rate fluctuations. These countries have been presenting, effectively, a 'dirty' floating exchange rate regime.

The implication expressed by the authors was that the frequent changes made in interest rates and international reserves by this group of emerging countries reflected their "fear of floating". This concern was justified by the fact that exchange 
rate exacerbated fluctuations were accompanied by an increase in the occurrence probability of sudden stops, since these exchange rate exacerbated fluctuations impacted the risk premiums demanded by international investors and vice-versa.

Calvo and Reinhart (2002) recognized that the risk premium attributed to emerging economies generally had a more volatile behavior. In this way, frequent changes in the domestic interest rate as a response to exchange rate volatility have been reducing the degree of autonomy of domestic monetary policy for these countries. Therefore, one can see that the guarantee of monetary policy independence within the context of a floating exchange rate and a deregulated capital account has not been delivered for emerging economies such as preconized by the impossible trinity presumption. ${ }^{32}$

The evidence of the procyclical behavior of net capital flows in relation to the business cycles of emerging economies gained greater adhesion in literature over the 00s. One of the implications of such dynamics is that the capital account and its financial linkages are getting even more hierarchically superior to the current account in determining capital inflows. This dynamic, as discussed in this article, induces a reduction in the degree of autonomy of domestic monetary policy in these countries, i.e., some of their macroeconomic variables, such as interest rates and exchange rate, are highly susceptible to external shocks and to economic policies of the developed countries.

In this sense, the study elaborated by Arora and Cerisola (2000) aimed to quantify the impacts that economic conditions in advanced countries had been exercising on the autonomy of emerging economies to implement their domestic policies. More precisely, the authors' concern was to measure the influence that changes in the Fed funds rate had been exercising on the sovereign bonds spreads of emerging economies, a proxy for the country's risk premium. The authors estimated, in isolation, regressions for a conjunct of emerging economies in which the dependent variable was the sovereign bonds spread of these economies, and the independent variables were the Fed funds rate, domestic factors, and a measure of future uncertainty in relation to the Fed funds rate.

The principle results of these regressions established that changes fostered by the Fed funds rate showed the highest impact, while the domestic factors of the country also played an important role. The authors further pointed out that the sovereign bonds spread of these emerging countries were subjected to contagious effects, in such a way that factors like external banking loans and mechanisms of cross border hedging significantly contributed to this kind of effect. Therefore, some of the external factors that have been contributing to negatively affect the autonomy of emerging economies to implement domestic policies were evidenced. One can also state that the monetary policy decisions are asymmetrically taken under

\footnotetext{
${ }^{32}$ Through different methods, Rey (2015) and Klein and Shambaugh (2015) reached a similar conclusion, i.e., that the impossible trinity is not valid for emerging economies.
} 
financial globalization, in which major developed economies are the ones who truly have a high degree of autonomy in implementing interest rate policies.

In addition, one of the most important issues about this subject is that the full long-term consequences of financial globalization were not well known at the time of the liberalizing reforms. For instance, it was expected that there would be an equal risk sharing between advanced and emerging economies, and that the growth of foreign liabilities and assets would take place in order to sustain the evolution of international commerce and Foreign Direct Investments (FDIs).

To the extent that financial globalization was getting more intense, several unforeseen dysfunctions and trade-offs started to appear. The extreme divergence in relation to risk sharing between advanced and emerging economies was well evidenced in the embracing studies published by Lane and Milesi-Ferretti (2007, 2015). The authors showed that de facto financial integration of advanced countries started to depart from the indicator of emerging economies in the beginning of 1990s, and the difference increased considerably through the 00s, a decade where a great deal of developing and emerging economies already showed a de jure liberalized capital account.

The joint analysis of these indicators showed that de facto financial integration has been increasingly greater for advanced countries, then indicating a greater capacity of risk sharing for this economic group. It is also noteworthy that risk sharing has gotten greater especially due to cross borders operations involving debt bonds. Lane and Milesi-Ferretti $(2007,2015)$ also pointed out that advanced countries that are considered financial centers, i.e., whose currencies are convertible in international financial markets, have a peculiar characteristic: these economies showed high volumes of gross external liabilities and assets while also showing a relatively low and constant Net External Position (NEP). It is notable that this last condition contributes to a less volatile exchange rate in developed economies, what in turn secures their monetary policy's high degree of autonomy.

In order to deepen the analysis on the divergences of the existing external positions, Lane and Milesi-Ferreti $(2007,2015)$ subdivided the external assets and liabilities in their components and found the following scenario: in a general way, advanced countries presented a positive net external position (NEP) for equities and FDIs and a negative NEP for debts, in such a way that the authors affirmed that the financial systems of these countries have been functioning like hedge funds. On the other hand, for the class of developing economies, a considerable number of these countries (about one third) showed an opposite composition, i.e., a negative NEP for equities and FDIs and a positive NEP for debt bonds.

This last group was essentiality constituted by emerging economies that were externally financed through equities and FDIs and that had extensive international reserves invested in the public debt bonds of advanced countries. Therefore, this class of emerging economies showed an external financial insertion that was unfavorable, since the charges on their foreign liabilities are much higher than the yields of their external assets, given the fact that the interest rates of advanced economies are relatively low. This returns differential has therefore constituted another coun- 
terfactual to the benefits of financial globalization being equally reaped and can be seen as a consequence of the inferior capacity of risk sharing of emerging economies.

Congruent to the evidence that the financial systems of advanced countries have a superior risk sharing capacity in relation to developing and emerging economies, the paper published by Bluedorn et al. (2013) also deserves attention for demystifying several concepts about capital flows volatility. The authors pointed out that the net capital inflows of emerging economies were, relative to their GDPs, higher and more volatile compared to those of advanced economies. One of the main determinants of this phenomenon was that the gross outflows of developed countries were greater in relation to those of developing economies. Furthermore, the gross outflows of advanced economies, especially the banking and debt bond flows, have been mostly flowing to other developed countries, which helps to explain the greater de facto financial integration and risk sharing among these countries.

In addition, Bluedorn et al. (2013) investigated if the volatility of capital flows were significantly different between these two classes of countries, in order to ratify or counterpoint the mainstream vision that the capital inflows of emerging economies show a relatively higher volatility. According to the authors' estimations, there were not statistically significant differences between the volatilities of net capital flows of advanced and emerging economies. However, a more disaggregated analysis established other results: several subcomponents of net capital inflows of advanced countries, especially debt bonds and banking flows, showed a higher degree of variability.

Two other characteristics of the two classes of countries analyzed differed: the level of gross capital outflows of emerging economies was inferior to the one observed for developed countries; however, the capital flows volatility of this class was greater than for the emerging economies. According to Bluedorn et al. (2013), this difference in the behavior of gross capital outflows between the two classes of countries has been influencing the behavior of net capital flows and, consequently, the movements of the nominal exchange rate, that being more volatile for emerging economies.

As described, apparently the advanced economies analyzed had a paradox: several subcomponents of net capital inflows were relatively more volatile in relation to the emerging economies; however, the aggregate volatility of net capital inflows did not show this behavior. According to Bluedorn et al. (2013), it occurred because the level of development of the financial system of developed countries is relatively superior. More specifically, the authors showed that there was, in the case of advanced economies, a strong and positive correlation among the subcomponents of gross outflows.

This strong degree of financial assets interchangeability, in turn, has been fostering a strong and negative correlation among net subcomponents of capital flows, that being a factor that guarantees a relatively constant level for this variable and, hence, for the nominal exchange rate of advanced countries. Besides this strong degree of interchangeability, the financial systems of developed economies have also been providing a high degree of complementarity of financial assets subcom- 
ponents, what in turn has also contributed to relative stability in their respective nominal exchange rates. Therefore, there was a strong and positive correlation between the gross capital inflows and gross capital outflows of these economies.

The main empirical evidence raised by Bluedorn et al. (2013) established that, contrary to what has been defended by a great share of mainstream literature, the volatility of capital flows has not been intrinsically greater for emerging economies. The appearance of this phenomenon, due to a higher variability of net capital inflows (and hence, of nominal exchange rate) observed for this group of countries, is because their financial systems do not have a similar level of development and sophistication in relation to what is observed in advanced countries.

\section{CONCLUSION}

The financial crises that hit emerging economies during the 1990s and the beginning of the first decade of the twenty-first century was an alarm to the fact that financial globalization could not be as functional and predictable as presumed in orthodox theory. The wave of studies that has taken place since then has been concerned with investigating the validity of such presumptions, as well as evidencing new phenomena derived from the global finance liberalization.

This article shown that there is no robust evidence that emerging economies are reaping the promised benefits of global finance. Important studies showed that emerging and developing countries reap the higher risks from the contemporaneous International Monetary and Financial System. The capital account liberalization of these countries did not promote higher economic growth and financial stability.

After two decades of empirical studies on financial globalization and its effects, it is necessary built a new open macroeconomic theory that considers all these dysfunctions derived from global finance, especially for developing and emerging countries, now recognized even by the mainstream economics.

\section{REFERENCES}

Alper, C. E., Ardic, O. P. and Fendoglu, S. (2009). "The economics of the uncovered interest parity condition for emerging markets”. Journal of Economic Surveys, 23(1), 115-138.

Arestis, P. (2009). "The new consensus in macroeconomics: a critical appraisal”. In Macroeconomic theory and macroeconomic pedagogy (pp. 100-117). Palgrave Macmillan, London.

Arora, V. B. and Cerisola, M. D. (2000). How does US monetary policy influence economic conditions in emerging markets? (No. 2000-2148). International monetary fund.

Bluedorn, M. J. C. et al. (2013). Capital flows are fickle: anytime, anywhere (No. 13-183). International Monetary Fund.

Bresser-Pereira, L. C.; Nakano, Y. (2003) “Crescimento econômico com poupança externa?” Revista de Economia Política, São Paulo, v. 23, n.2, p. 3-27, 2003.

Bresser-Pereira, L. C.; Gala, Paulo. (2007) “Por que a poupança externa não promove crescimento?” Revista de Economia Política, São Paulo, v. 27, p. 3-19, 2007. 
Calvo, G. A., Izquierdo, A. and Mejia, L. F. (2004). On the empirics of sudden stops: the relevance of balance-sheet effects (No. w10520). National Bureau of Economic Research.

Calvo, G. A., and Reinhart, C. M. (2002). "Fear of floating”. The Quarterly Journal of Economics, 117(2), 379-408.

Dooley, M. P. (1996). “A survey of literature on controls over international capital transactions”. Staff Papers, 43(4), 639-687.

Edwards, S. (2007). "Capital controls, sudden stops, and current account reversals". In Capital controls and capital flows in emerging economies: Policies, practices and consequences(pp. 73-120). University of Chicago Press.

Eichengreen, B., Hausmann, R. and Panizza, U. (2003). “The pain of original sin.” In Other People's Money: Debt Denomination and Financial Instability in Emerging Market Economies, University of Chicago Press, Chicago.

Eichengreen, B., Hausmann, R. and Panizza, U. (2007). "Currency mismatches, debt intolerance, and the original sin: Why they are not the same and why it matters". In Capital controls and capital flows in emerging economies: Policies, practices and consequences (pp. 121-170). University of Chicago Press.

Henry, P. B. (2007). “Capital account liberalization: Theory, evidence, and speculation”. Journal of Economic Literature, 45(4), 887-935.

Kaminsky, G. L., Reinhart, C. M. and Végh, C. A. (2004). "When it rains, it pours: procyclical capital flows and macroeconomic policies". NBER macroeconomics annual, 19, 11-53.

Klein, M. W. and Shambaugh, J. C. (2015). "Rounding the corners of the policy trilemma: sources of monetary policy autonomy”. American Economic Journal: Macroeconomics, 7(4), 33-66.

Kose, M. A., Prasad, E., Rogoff, K. S. and Wei, S. J. (2006). Financial globalization: a reappraisal (No. w12484). National Bureau of Economic Research.

Lane, P. R. and Milesi-Ferretti, G. M. (2007). "The external wealth of nations mark II: Revised and extended estimates of foreign assets and liabilities, 1970-2004.” Journal of international Economics, 73(2), 223-250.

Lane, P. R. and Milesi-Ferretti, G. M (2015). "The External Wealth of Nations Mark II: Revised and Extended Estimates of Foreign Assets and Liabilities", 1970-2015. mimeo.

Prasad, E. S., Rajan, R. G. and Subramanian, A. (2007). Foreign capital and economic growth (No. w13619). National Bureau of Economic Research.

Prasad, E. S., Rogoff, K., Wei, S. J. and Kose, M. A. (2003) Effects of Financial Globalization on Developing Countries: Some Empirical Evidence. IMF Occasional Paper No. 220. International Monetary Fund.

Reinhart, C. M., Rogoff, K. S. and Savastano, M. A. (2003) Debt Intolerance. (No. w9908). National Bureau of Economic Research.

Rey, H. (2015). Dilemma not trilemma: the global financial cycle and monetary policy independence (No. w21162). National Bureau of Economic Research.

Rodrik, D. (2006). "The social cost of foreign exchange reserves". International Economic Journal, 20(3), 253-266.

Rodrik, D. and Subramanian, A. (2009). "Why did financial globalization disappoint?” IMF staff papers, 56(1), 112-138.

Rodrik, D. and Velasco, A. (1999). Short-term capital flows (No. w7364). National Bureau of Economic Research. 